\title{
PRAVNI SUSTAV ZAŠTITE ŽIVOTA, ZDRAVLJA I DOBROBITI ŽIVOTINJA - BIOETIČKI PRISTUP U PRAVNOM OKVIRU
}

\author{
Tomislav Nedić
}

Pravni fakultet, Sveučilište J.J. Strossmayera u Osijeku Orahovička 47, 31000 Osijek e-mail: nedict@gmail.com

Sažetak

Još od davnih vremena, uloga životinje u čovjekovu životu bila je itekako zamjetna i bitna. Takoder, suživot čovjeka $i$ životinje, ali i čovjeka i cjelokupnog živog svijeta od velike je važnosti za očuvanje prirodne ravnoteže u biosferi. Samim time, bioetička osviještenost čovjeka prema životinjama raste te pokreće zanimljiva pravna razmatranja iz kojih izviru određena pitanja. Pravni sustav zaštite života, zdravlja i dobrobiti životinja preduvjet je mirnom i staloženom suživotu čovjeka i životinje. Primjenom poredbenopravne, case law, povijesne i analitičke metode u radu se kritički razmatra cjelokupni pravni sustav zaštite života, zdravlja i dobrobiti životinja u Republici Hrvatskoj i svih onih elemenata koje pravni sustav sa sobom nosi. Cilj je ovog rada odgovoriti na pitanja smatraju li se trenutno životinje subjektima ili objektima prava, imaju li subjektivna prava ili se radi o zaštićenim pravnim dobrima, te na koji način pravni izvori u Republici Hrvatskoj reguliraju ovo pitanje is stite li oni izravno integritet životinje. Istraživanje u ovom radu iznjedrilo je zaključak kako se životinje trenutno smatraju pravnim objektima (s naglašenom tendencijom u praktičnim i teorijskim krugovima za promjenom tog statusa) kojima pravni sustav garantira zaštitu njihova života, zdravlja i dobrobiti kao zaśtićenih pravnih dobara koje izravno štiti vlastitim propisima, prije svega, novim Zakonom o zaštiti životinja te blanketnim odredbama kaznenog djela ubijanja ili mučenja životinja u Kaznenom zakonu. Odgovori na pravna pitanja samo su malen, ali itekako bitan korak u izgradnji sustava ljudske solidarnosti prema životinjama u vidu mirnog i neometanog suživota čovjeka $i$ životinje.

Ključne riječi: bioetika, dobrobit, pravo, život, životinje

\section{UVODNE POSTAVKE ${ }^{1}$}

\subsection{Pravo životinja}

Suživot čovjeka i životinje jedna je od onih tema koja pripada domeni bioetike kao znanstvene discipline. Iako njezina definicija obuhvaća mnogobrojne elemente koji se moraju uzeti u obzir, bioetiku možemo definirati kao pluriperspektivno područje u kojem se u

1 Prvotna istraživanja iznesena u ovom radu prezentirana su u okviru „1. Osječkih dana bioetike“ na međunarodnoj konferenciji „Bioetika i okoliš - otvara li CETA vrata za GMO?“ održanoj 2017. godine 
interakciji raznorodnih perspektiva stvaraju uporišta i mjerila za orijentiranje u pitanjima koja se odnose na život ili na uvjete i okolnosti njegova očuvanja (Čović, 2004:11). Bioetičko pitanje suživota čovjeka i životinje te zaštite života, zdravlja i dobrobiti životinje u ovom radu promatrat ćemo kroz prizmu pozitivnog prava i trenutne situacije, i u teorijskom, ali prije svega, u pragmatičnom smislu. Rad je multidisciplinarnog i interdisciplinarnog karaktera te u sebi obuhvaća elemente bioetike, kaznenog prava i teorije prava. Pravo životinja nova je pravna grana u kojoj postoji još dosta prostora za različita interdisciplinarna istraživanja. Pravo životinja u objektivnom smislu, u literaturi definira se kao skup pravnih pravila, kojima se regulira postupanje ljudi prema životinjama i osigurava zaštita njihove dobrobiti (Stojanović, 2017:7). Pravo životinja nema univerzalnu definiciju s obzirom da je, u jednu ruku, njezino postojanje kontroverzno jer životinje u pravnom smislu nemaju subjektivna prava pa bi i postojanje objektivnog prava u tom pogledu bilo neutemeljeno. ${ }^{2}$ No valja istaknuti da takvo mišljenje nije pravnoteorijski utemeljeno i da mu se mogu uputiti stanovite zamjerke. Objektivno pravo ne mora nužno biti određeno s obzirom na pravne subjekte, nego s obzirom na činjenicu da isto pravo predstavlja skup normi kojima se regulira određeno područje, točnije postupanje ljudi u tom području, npr. pravo mora koje postoji kao zasebna pravna grana unutar međunarodnog prava. Samim time, pravo životinja, nije određeno $s$ obzirom na životinje, nego s obzirom na ljude kao adresate pravnih normi iz područja zaštite dobrobiti životinje, regulirajući time bioetički aspekt suživota čovjeka i životinje. Tako se, primjerice, kazneno djelo ubijanja ili mučenja životinja odnosi upravo na ljude, zabranjujući svako neopravdano nasilno ponašanje prema životinji. Zakon o zaštiti životinja (NN 102/17) također se odnosi na ljude kao adresate njegovih normi.

Shvaćanje dobrobiti životinja podložno je povijesnim mijenama. Tako je, primjerice, za određene farmere i veterinare taj pojam obuhvaćao isključivo zaštitu tijela životinje i osiguranje dobrih vanjskih uvjeta pa tako ako je životinja zdrava i proizvodi hranu smatralo se da joj je cjelokupna dobrobit očuvana (Hewson, 2003:497). No, prema najnovijim znanstvenim istraživanjima, dobrobit životinja obuhvaća nekoliko bitnih faktora. Tako dobrobit životinja kao pojam podrazumijeva zaštitu tijela životinje, njihovih osjećaja te omogućavanje života u skladu s njihovom prirodom i ostvarivanja punog opsega njihovog prirodnog ponašanja (Hewson, 2003:497). U radu će se koristiti termin zaštite zdravlja, života i dobrobiti životinja, sukladno terminologiji Zakona o zaštiti životinja. Kod pitanja zaštite života, zdravlja i dobrobiti životinja u svakom pravnom sustavu, kao ljudskoj tvorevini, do izražaja dolazi konfrontacija između antropocentrične i biocentrične etike te pitanje je li pravni sustav uistinu okrenut zaštiti života, zdravlja i dobrobiti životinja ili pak onoj regulaciji koja više ide na ruku čovjeku i stavlja njega kao središnju točku? Pravilan i uravnotežen suživot čovjeka i životinje ovisi upravo o ovom konceptu te je na čovjeku da isti suživot pokuša što je više moguće uklopiti u suvremeno funkcioniranje društva.

2 Potrebno je istaknuti kako u hrvatskom jeziku termin pravo obuhvaća subjektivno i objektivno pravo. Pa je tako subjektivno pravo životinje u stranoj literaturi na engleskom jeziku određeno kao animal right, a objektivno pravo životinja kao animal law. 


\subsection{Sadržaj i cilj rada}

Cilj je ovog rada cjelovito razraditi pitanje pravne zaštite života, zdravlja i dobrobiti životinja. S tim u vezi, pragmatički se razmatra koji je trenutni status životinja u pravu (pravni subjektivitet ili objektivitet), mogu li prema tom viđenju životinje imati subjektivna prava te jesu li život, zdravlje i dobrobit njihova prava ili pravna dobra. Nadalje, kritički se analiziraju glavni izvori prava ovog područja u nas te se pokušava uvidjeti štite li se tim izvorima (ratio legis) izravno život, zdravlje i dobrobit životinja. Poredbenopravno nudi se teorijska i pragmatična usporedba hrvatskog i njemačkog pravnog sustava. U prvom dijelu rada razmatra se pitanje životinjskog objektiviteta te potencijalnog subjektiviteta. Primjenom case law metode prikazuje se i razrađuje trenutno stanje stvari, ali i postavljaju bitna pitanja iz područja teorije prava na koja je potrebno odgovoriti daljnjim istraživanjima unutar navedene pravne grane kako bi se konačno odredilo mogu li životinje biti subjekti prava. Povijesnom metodom, uspoređuje se pravni status životinja u povijesti i danas. Uz to, u istom se dijelu, uz bitna pitanja na kraju, razmatra pitanje mogu li životinje imati subjektivna prava ili su život, zdravlje i dobrobit zaštićena pravna dobra, ali ne i pravno označena subjektivna prava. $U$ drugom dijelu analiziraju se glavni izvori ovog područja u Hrvatskoj: Zakon o zaštiti životinja i Kazneni zakon. Kritički se analiziraju novine ovih zakona, razrađuje se razlika između prekršaja i kaznenog djela kod bilo kakve povrede integriteta životinje, te se razrađuju potencijalna ograničenja zaštite integriteta životinje, eksplicitno Zakonom o zaštiti životinja te metodom case law kod pitanja narodnih običaja. Na kraju poglavlja, odgovara se na pitanje štiti li cjelokupni pravni sustav (biocentrično) izravno život, zdravlje i dobrobit životinja ili društvenu ljudsku zajednicu i sustav od bilo kakvog oblika nasilnog ponašanja koje bi potencijalno moglo biti štetno za samog čovjeka (antropocentrično).

\section{PRAVNI STATUS ŽIVOTINJA}

\subsection{Pravni objektivitet $i$ potencijalni subjektivitet životinja}

Pitanje pravnog subjektiviteta životinja zasigurno je zasebno pitanje unutar ove teme koje također zahtijeva i posebnu pravnoteorijsku razradu. Pravni subjektivitet životinja itekako je izazovna tema, tema budućnosti o kojoj će zasigurno pravnoteorijski znanstvenici još mnogo toga reći. No, ovoj temi, pogotovo u dijelu gdje se razmatra smatraju li se životinje nositeljima prava ili se radi o zaštiti života, zdravlja i dobrobiti kao pravnom dobru, ne može se pristupiti bez da se prethodno ne priopći u čemu se sastoji kontroverznost životinjskog subjektiviteta i objektiviteta. Nadasve, za daljnja istraživanja, ali i potrebe ovog rada, potrebno je razmotriti koja pitanja, ali i razmatranja, prije svega pragmatična, sa sobom nosi problematika subjektiviteta životinja, u kojim se realnim situacijama postavlja pitanje subjektiviteta životinja te kako se kroz povijest gledalo na pravni status životinja. Još od rimskog prava, životinja je smatrana objektom, odnosno bila je smatrana stvari. Tada se pravila razlika između divljih životinja (lat. ferae bestiae) koje su živjele u prirodnoj slobodi i bile tretirane kao res nullius pa ih je svatko mogao uloviti i tako steći 
vlasništvo te onih koje su bile pripitomljene (Romac, 1983:30). Za ove posljednje uzimalo se da pripadaju vlasniku sve dotle dok imaju naviku da se vraćaju kući (animus revertendi), ali čim to prestanu raditi, ponovno postaju res nullius (Romac, 1983:30). Ničija stvar (res nullius) u užem smislu su samo stvari koje mogu biti predmetom prometa, ali časovito nisu u ničijem vlasništvu, ili stvari koje još nikada nisu bile u ničijem vlasništvu, kao npr. divlje životinje u prirodi (Horvat, 2008:161). Tako Gaj piše kako su divlje životinje, ako su pripitomljene i naviknute da dolaze i odlaze, lete i dolijeću, kao što su jeleni, labudovi itd., u ljudskoj svojini i takvim se smatraju sve dok su sklone da se vraćaju natrag (Stojčević i Romac, 1971:40). ${ }^{3}$ Poseban su status imale tovarne domaće životinje i one koje se uprežu jer je njihova korist za čovjeka tada bila itekako velika te se njihova predaja mogla obaviti samo formalističkim pravnim aktom (tzv. res mancipi). Još od davnina, određene životinje trpe negativne ljudske predrasude, primjerice, zmija koja se smatrala oglednim simbolom zla. Slična je situacija i s gavranom koji uživa prvenstvo kao smradni stvor i Sotonin izdanak, dok je golubica dražesna živina i izabrana posuda za izlijevanje Duha Svetoga, obličje u kojem se utjelovila treća osoba Svetog Trojstva (Payson Evans, 2014:36). Tako je u srednjem vijeku zabilježeno 189 sudskih procesa koji su se vodili protiv životinja kao prvooptuženih. U svojoj knjizi Edward Payson Evans (Payson Evans, 2014) prvi puta objavljenoj 1906. godine, pobliže opisuje najneobičnije, najzanimljivije te najpraznovjernije sudske procese koji su se vodili protiv životinja, a inicirala ih je uglavnom Crkva te su vrlo često imali religijski karakter. Procesi su se vodili protiv kukaca, domaćih i divljih životinja. Tako je, primjerice, svinja optužena za ubojstvo djeteta i osuđena na kaznu vješanja. Kažnjavali su se kukci koji su uništavali usjeve, vinovu lozu itd. Iz navedenoga bi se moglo zaključiti kako su životinje tada smatrane određenim subjektima prava jer su imale procesnopravnu sposobnost, no navedena suđenja u većoj mjeri nisu imala pravno utemeljene razloge. Tako se, primjerice, navodi kako je 1478. godine u Švicarskoj pred biskupom Lausanne održano suđenje kukcu ingeru, kornjašu iz roda Brychus zbog učinjene štete na usjevima. (Bio) etički gledano, isti kukac nije učinio nikakav grijeh (delikt) jer je samo zadovoljavao svoje osnovne egzistencijalne potrebe niti je u pravnom smislu kršio određene propise koji teško da su bili kodificirani na taj način da se takvo nešto zabranjuje životinjama. Isti su procesi bili vođeni jer je smatrano kako su iste životinje Sotonin instrument protiv ljudi i samog Boga te je velik broj presuda sadržavao određenu egzorcističku formu kako bi se Sotona istjerala iz same životinje. ${ }^{4}$ Tako stoji i u opomeni ingeru kako će „gospodar Lau-

3 Lat. Animalia fera, si facta mansueta et ex consuetudine eunt et redeunt volant et revolanst, ut cervi, cygni, etc. eo usque nostra sunt et ita intelliguntur quamdiu habuerunt animum revertendi. Sec. Gaius - D. 41, 1, 5 ,5 (Stojčević i Romac, 1971:40)

4 Do koje je granice detaljno i, naravno ipak pomalo apsurdno, sezalo crkveno-teorijsko stajalište kako su određene životinje Sotonin „stan“ svjedoči i posebna rasprava oca Bougeanta oko pitanja može li se sotona nastaniti u svim životinjama, pa čak i malim kukcima. Pa tako on tvrdi kako je „Bog mogao stvoriti čovjeka malenim poput lisne uši, a da ne umanji njegove duhovne moći. Da bi đavao mogao biti utjelovljen u tanašnom tijelu mušice stoga nije ništa teže vjerovati nego da je u golemom trupu slona“ (Payson Evans, 2014:57). 
sanne (misleći na biskupa) ili njegov zamjenik protiv njega, u skladu s pravilima pravde, povesti postupak kletvama ili drugim egzorcizmima, kao što je primjereno u takvim slučajevima prema pravnoj formi i ustaljenoj praksi“ (Payson Evans, 2014:79). U tome se vidi kako nije postojala konkretna pravna norma, nego se tvrdi kako se postupa prema pravilima pravde, dok se kazna sastojala od procesa egzorcizma i drugih kletvi. ${ }^{5}$ Navedeni procesi pokazatelj su i velikog religijskog praznovjerja ljudi u mračnom dobu kao što je bio srednji vijek. Stoga se ovdje ne radi o klasičnom pravu niti pravnom postupku, niti o pravnom subjektivitetu životinje iako se određeni dio procesa odvija u nadležnosti ovlaštenih sudskih tijela, pod utjecajem Crkve tako da je svakoj životinji dodijeljen i ovlašteni branitelj. No, određeni postupci nisu uopće imali pravni značaj i konotaciju, nego su bili isključivo odraz pukog ljudskog praznovjerja i bezrazložnog nasilja prema životinjama. Zanimljivo je kako je nekoliko seljana u Vidovićima kraj Požege, mnogo kasnije, 1866., uz prisutnost drugih seljana, zbog velike pošasti skakavaca u to vrijeme, uhvatilo jednog skakavca, osudilo ga na smrt te bacilo u rijeku Orljavu uz proklinjanje (Payson Evans, 2014:201). S obzirom na upitnu pravnu valjanost i opravdanost istih postupaka, teško da se u preciznim i znanstveno utvrđenim pravnoteorijskim aspektima može govoriti o pravnom subjektivitetu životinje kao dioniku sudskog procesa.

Danas se, pogotovo u pravnoj praksi, po uzoru na rimsko pravo, životinje smatraju objektima prava. Objektivitet životinja dio je i kaznenopravne dogmatike. Tako se, primjerice, kod krajnje nužde koja isključuje protupravnost, ubijanje psa radi spašavanja vlastitog života ocjenjuje kao manje zlo od onog koje je prijetilo (isključenje protupravnosti), dok se kod krajnje nužde koja isključuje krivnju u primjeru ubijanja čovjeka radi spašavanja vlastitog života uzima da učinjeno zlo nije nesrazmjerno teže od zla koje je prijetilo (Novoselec i Bojanić, 2013:187). Objektivitet životinja dolazi do izražaja i u sudskoj praksi gdje se povreda životinjskog integriteta karakterizira i kao kazneno djelo oštećenja tuđe stvari, ako je životinja u vlasništvu određene osobe. Tako je u jednom slučaju (Županijski sud u Osijeku, Kž-329/02 od 28. 6. 2002., Općinski sud u Belom Manastiru, K-61/02) počinitelj u idealnom stjecaju počinio kazneno djelo mučenja životinje i kazneno djelo uništenja ili oštećenja tuđe stvari, no osuda i za to kazneno djelo nije bila moguća jer se kazneni postupak za uništenje i oštećenje tuđe stvari pokreće u povodu prijedloga, a njega nije bilo (Novoselec, 2004:284). No, u zadnje se vrijeme, prema određenim istraživanjima (Ascione i Lockwood, 2001) pojavljuje sve više situacija gdje sudovi razmatraju problematiku subjektiviteta životinja. Ne radi se samo o pravosuđu, nego i ostalim područjima ljudskog djelovanja, pa se samim time postavlja i zanimljivo pitanje mogu li životinje biti uistinu smatrane subjektima prava?

5 U presudi je stajalo: „U skladu s tim optužujemo ih i teretimo našim prokletstvom i zapovijedamo im da budu poslušni i anatemiziramo ih u ime Oca, Sina i Duha Svetoga da se odvrate od svih polja, posjeda, ograđenog tla, sjemena, plodova i uroda te da odu. Na temelju iste presude objavljujem i potvrđujem da ste prognani i egzorcirani i zahvaljujući moći Boga Svemogućega zvat će vas prokletima i svakog će vas dana biti sve manje kamo god da odete kako od vas ništa ne bi ostalo osim na upotrebu i korist čovjekovu“ (Payson Evans, 2014:82). 
To je pitanje došlo do izražaja kod sisavaca koji se koriste u ratne svrhe ${ }^{6}$, a posebno kod zarobljenih dupina ukrajinske vojske koje je zarobila ruska vojska u Krimskom ratu gdje se postavilo valjano pitanje mogu li isti dupini i službeno dobiti status ratnih zarobljenika (engl. Prisoner of War), jer su praktički i držani kao ratni zarobljenici. Prema Ženevskoj konvenciji o postupanju s ratnim zarobljenicima iz 1949., u čl. 4. navodi se kako su „ratni zarobljenici, u smislu ove konvencije osobe koje pripadaju jednoj od sljedećih kategorija, a koja su pala pod vlast neprijatelja" (Sassòli i sur., 2011:10).7 Potrebno je naglasiti kako nije eksplicite navedeno da se mora raditi o ljudskim osobama. U literaturi iz međunarodnog humanitarnog prava navodi se kako „ratni zarobljenik ima pravo na odgovarajući status i postupanje uspostavljeno međunarodnim pravom, te je subjekt prava, regulacija i općeg poretka na snazi u oružanim snagama Sile pod čijom se vlašću nalaze" (Verri, 1992:87). U toj definiciji jasno se može tumačiti kako ratni zarobljenik ima zagarantirana prava, ali da se riječ „subjekt“ u istom navodu prije svega odnosi na dužnosti koje ratni zarobljenik ima prema Sili pod čijom se vlašću nalazi. Za sve što se dogodi ratnim zarobljenicima odgovara upravo Sila pod čijom se vlašću oni nalaze, odnosno radi se o odgovornosti države koja ni u jednom trenutku ne umanjuje i odgovornost individualnih osoba koja može nastati iz kršenja propisa same konvencije (Kalshoven i Zegveld, 2011:53). Također, odnos vojnika i vojnih sisavaca itekako je zanimljiv, pa tako i izjava jednog američkog marinca koji za jednog od pasa američke vojske tvrdi: „On nije pas, on je marinac“ (Krizmanić, 2016:89). Prema svemu navedenom, tumačenjem odredbi vojnog i međunarodnog humanitarnog prava, ratni dupini ili vojni lavovi mogli bi se smatrati osobama, ali i ratnim zarobljenicima koji su subjekti prava, što bi vodilo do zaključka kako bi se, barem u vojnim krugovima, iste životinje mogle smatrati pravnim subjektima. Pravo je samo po sebi univerzalno te su akti međunarodnog humanitarnog prava ratificirani u brojnim državama u svijetu i dio su pravnog poretka Republike Hrvatske.

Također, u određenim se zakonodavstvima vidi jasna i pomalo pravnorevolucionarna tendencija da se promijeni pravni status životinje ustanovljen još u rimskom pravu.

6 U tom pogledu, najviše se koriste dupini, ali i npr. morski lavovi i kitovi. Dupini kao sisavci, zbog izuzetnih kognitivnih sposobnosti, koriste se ponajviše kod detektiranja podvodnih mina, ali i ostalih vojnih podvodnih potreba. No, njihovo korištenje u vojne svrhe u smislu vojnog oružja itekako je dvojbeno etičko pitanje koje je naišlo na brojne polemike, rasprave, ali i negodovanje javnosti. Ipak, upotreba životinja u ratne svrhe nije novina. Psi, golubovi, konji, slonovi itd. u prošlosti se stoljećima koriste u vojne svrhe, dok je dresura ratnih vojnih pasa jedna od važnijih u vojnoj i policijskoj službi. 7 Kategorizacija dupina ovisila bi o njihovoj ulozi. Ako se dupin koristi u čisto ratne svrhe, tada bi se na istog dupina odnosio stavak 1 . „pripadnici oružanih snaga jedne strane u sukobu, kao i pripadnici narodne vojske i dobrovoljnih jedinica koji ulaze u sastav tih oružanih snaga“. Ako se dupin koristi u neratne svrhe, npr. razminiravanje područja, tada možemo reći kako bi se na njega trebao primjenjivati stavak 4: „osobe koja prate oružane snage iako neposredno ne ulaze u njihov sastav, kao što su civilni članovi posada vojnih zrakoplova, ratni dopisnici, dobavljači, članovi radnih jedinica ili službi čija je dužnost da se brinu o udobnosti oružanih snaga, pod uvjetom da su za to dobili dozvolu od oružanih snaga u čijoj se pratnji nalaze, dok su ove dužne da im u tu svrhu izdaju osobnu iskaznicu sličnu priloženom obrascu““ (Sassòli i sur., 2011:10). 
Tako je potrebno spomenuti i odredbu njemačkog Građanskog zakonika (čl. 90a) u kojem stoji: „Životinje nisu stvari. One će biti zaštićene posebnim zakonima. Na njih se primjenjuju propisi koji važe za stvari, ako nije određeno što drugo" (Bürgerliches Gesetzbuch, 1896). Ova odredba ipak predstavlja svojevrsnu pravnu revoluciju i uistinu velik korak tendenciji da se, prije svega, životinje više ne smatraju objektima te da se barem otvori pitanje njihova subjektiviteta.

No, subjektivitet životinja kompleksna je postavka koja povlači sa sobom i pravnoteorijska pitanja. Mogu li životinje biti subjektima prava, ako nisu svjesne što znači biti nositeljem prava i dužnosti? Subjekt prava jest nositelj prava i dužnosti te ako bi se pravno priznala određena prava životinjama, došli bismo do pitanja koje točno dužnosti imaju životinje kao subjekti prava? Potrebno je kod ovog pitanja istaknuti kako postoje i određeni pravni subjekti koji imaju određena prava bez dužnosti, npr. djeca, pa je tako prikladno pitanje mogu li životinje, koje nisu pravni subjekti, imati subjektivna prava te u čemu se ona ogledaju? Vođen idejama iz djela Toma Regana (1983), Visković (1992:288) ističe potrebu priznanja pravnog subjektiviteta životinjama i pridavanja nekim ili svim ljudima statusa zastupnika subjektivnih prava životinja. Sličnu tvrdnju zastupa i Adams (2009:42) tvrdeći da kada bi se životinjama i dao pravni subjektivitet to ne znači da one više ne bi bile subjekti o kojima skrbe i koja kontroliraju ljudska bića, nego samo to da ljudi više ne bi bili vlasnici životinja. Odnos između čovjeka i životinje bio bi sličniji odnosu između roditelja i djeteta ili duševno bolesne osobe i njezina zakonskog zastupnika (Adams, 2009:42). Također, priznanjem subjektiviteta životinjama došlo bi do brojnih posljedica kod trenutnog suživota ljudi i određenih životinja. Tako, primjerice, kao što je već navedeno, ljudi više ne bi mogli imati pravo vlasništva nad životinjama. Pravnoteorijski aspekt životinja kao nositelja prava te životinja kao subjekata prava zasigurno je zasebno područje ove teme koja zahtijeva posebno istraživanje unutar teorije prava. No, prema svemu navedenom, u pravu je još uvijek više zastupljeno stajalište o životinjama kao pravnim objektima, iako je u određenim istraživanjima, praksi, ali i zakonodavstvima (navedeno njemačko), sve više prisutna tendencija da se životinje više ne smatraju stvarima te da se razmotre pitanja njihova pravnog subjektiviteta i subjektivnih prava ili barem tzv. posebno zaštićenih objekata sui generis (Vrban, 2003:296) koje određeni ljudi zastupaju.

\subsection{Tipologija života, zdravlja i dobrobiti životinja - subjektivna prava ili zašti- ćena pravna dobra}

Poput subjektiviteta životinja, pitanje subjektivnih prava životinja, koje emanira upravo iz pitanja pravnog subjektiviteta životinja i neodvojivo je od tog pitanja, posebno je pravnoteorijsko pitanje koje zahtijeva temeljitu, sofisticiranu i kompleksnu razradu unutar teorije prava. Najprije valja napraviti distinkciju između pojmova subjektivnog prava i pravnog dobra te razmotriti jesu li život i zdravlje životinje subjektivno pravo životinje ili zaštićeno pravno dobro koje pravni poredak štiti. Potom je potrebno napraviti distinkciju između prava u pravnom i moralnom smislu. Naročito u slučajevima kada se koristi izraz „životinjskih prava“, uvelike ostaje nedorečeno o kojim se pravima radi. 
Tako DeGrazia (2002:20), nasuprot pravima u pravnom smislu, na deontološkom i utilitarističkom tragu, razmatra životinjska prava u moralnom smislu, i to u tri aspekta: aspektu moralnog statusa životinje (životinje ne postoje samo zbog ljudskog korištenja njima te bi ih se trebalo valjano tretirati zbog njihove dobrobiti), aspektu jednakog razmatranja (jednaka moralna težina usporedivih ljudskih i životinjskih interesa - npr. životinjska patnja vrijedi isto kao i ona ljudska) i aspektu sredstva korisnosti (kao i ljudi, životinje imaju određene vitalne interese preko kojih čovjek ne smije prijeći, čak i u onoj situaciji kada bi to donijelo veliku korisnost društvu).

Subjektivno pravo jest pravo nekog subjekta da $s$ nečim raspolaže i da nešto zahtijeva (Vrban, 2003:307). Subjekt prava nositelj je prava i dužnosti, no postoje i oni subjekti prava koji nemaju dužnosti, npr. djeca, pa se s tim u vezi postavlja i pitanje podrazumijeva li pravo sa sobom i dužnost? Upravo kako spominje DeGrazia, interes osobe i jest jedan od glavnih parametara kod toga je li netko nositelj prava i u pravnom smislu, pa i u teoriji prava prevladavaju dvije teorije: voljna i interesna teorija. Teoriji volje blisko je i shvaćanje subjektivnih prava koje polazi od vlasti (moć, gospodstvo) koju ima subjekt nad stvarima i drugim objektima prava (Vrban, 2003:312). Slobodno prisvajanje i raspolaganje bit je stvarnih prava i osobito prava vlasnika (Vrban, 2003:312). Kao i vlast, tako je i ovlaštenje sadržaj subjektivnih prava te se to shvaćanje podudara s koncepcijom volje, a njemu se danas priklanja velika većina autora (Vrban, 2003:312). S druge strane, teorija interesa nastala je pod utjecajem njemačkog pravnika Rudolpha von Iheringa prema kojemu je volja apstraktan i besadržajan pojam te kao takva ne odgovara stvarnom životu ni potrebama ljudi kojima pravo služi, jer Ihering primjećuje kako prava imaju i one osobe u kojih ne postoji volja (djeca, „luđaci“), pa je, po njemu, teorija volje „čista fikcija“ (Vrban, 2003:312). Po Iheringu, volja nije samo odraz pojedinačne, nego i opće volje koja stvara cjelokupno objektivno pravo, pa tako opća, kao i pojedinačna volja ne pogađa bit prava koja se temelji na konkretnim interesima subjekata (Vrban, 2003:312). Interesna teorija može dati životinjama status nositelja prava u smislu da životinje poput ljudi imaju određene vitalne interese, no prema voljnoj teoriji životinje, kao eventualni nositelji prava, nisu sposobne donositi „one odluke koje se odnose na ponašanje drugih" (Kramer, 2001:29). ${ }^{8}$ Voljna teorija samim time uvelike sužava potencijalne nositelje prava, poput životinja i mrtvih osoba te bi se o životinjama kao nositeljima prava eventualno moglo raspravljati u okviru interesne teorije. Kritičari ističu da zakoni često stvaraju dužnosti koje nisu korelativne pravima (Tucak, 2017:202). Primjerice, iako imamo pravne dužnosti prema zakonima o dobrobiti životinja ne postupati okrutno prema njima, ne može se reći da životinje imaju zakonska prava (Wellman, 1997:2; Usp. White, 1984:61). Dužnosti postoje „s obzirom na“ životinje, a „ne

8 Tako Kramer, kao zastupnik interesne teorije, tvrdi kako se interesna teorija može ukratko sažeti u dvije glavne teze: a) nužno, ali nedovoljno za stvarno ovlaštenje prava koje ima osoba X jest da pravo, kada se uistinu ima, štiti jedno ili više od X-ovih interesa; b) niti dovoljno niti nužno za X-ovo ovlaštenje prava jest očita činjenica da je $X$ sposoban i ovlašten zahtijevati ili odreći se provođenja tog prava (Kramer, 2001) . 
prema njima“ (Freeman, 2008:395). U vrijeme dok je u SAD-u ropstvo bilo legalno, gospodar je imao apsolutne dužnosti prema robovima, ali robovi nisu imali prava (White, 1984:63). Brojni su teoretičari razrađivali interesnu i voljnu teoriju te se radi o onom području gdje još nije utemeljeno univerzalno znanstveno mišljenje o tome tko točno može biti nositeljem prava te što uistinu pravo sa sobom nosi.

$S$ druge strane, pravno dobro obuhvaća društvene vrednote koje pravni poredak štiti prijetnjom kazne, ne samo propisivanjem kaznenih djela, nego i prekršaja, ali kaznena djela služe zaštiti naročito vrijednih pravnih dobara koje Ustav u čl. 3. označuje kao najviše vrednote ustavnog poretka Republike Hrvatske (Novoselec i Bojanić, 2013:127). Svako kazneno djelo je ugrožavanje ili povreda nekog pravnog dobra, iako to pravno dobro nije sastavni dio opisa kaznenog djela, tj. nije u inkriminaciji neposredno izraženo (Vidaković Mukić, 2006:857). Upravo zato je identifikacija pravnog dobra, odnosno identifikacija vrijednosti koja se štiti kaznenom normom, bitna za ispravno tumačenje smisla bića nekog kaznenog djela (Vidaković Mukić, 2006:857). Bitno je spomenuti kako Vrban (2003:289) razlikuje ljudske tvorevine i prirodna dobra, gdje potonjim možemo smatrati prirodu i čovjekov okoliš. Visković (2001:211) u tom pogledu odlazi korak dalje te taksativno, između ostalog, navodi životinje kao prirodna dobra. $\mathrm{Uz}$ to potrebno je napomenuti kako svi navedeni autori pravna dobra smatraju pravnim objektima, što je još jedan od argumenata klasičnom shvaćanju životinja kao objekata prava. Na temelju svega rečenog, kako su propisani temeljnim vrednotama ustavnog poretka (očuvanje prirode i čovjekova okoliša), kaznenim djelom ubijanja ili mučenja životinja među kaznenim djelima protiv okoliša te Zakonom o zaštiti životinja (NN 102/17) i Zakonom o zaštiti prirode (NN 80/13) - život, zdravlje i dobrobit životinja spada u pravna dobra koja pravni sustav štiti u kontekstu očuvanja prirode i čovjekova okoliša.

Prema tome, u skladu s dosadašnjim istraživanjima i razmatranjima u pravnoj teoriji i praksi, kako još uvijek ne postoji univerzalno i znanstveno utemeljeno stajalište o tome mogu li životinje biti nositeljima prava, bez dužnosti i bez da pritom imaju utvrđeni pravni subjektivitet, najpreciznije je život, zdravlje i dobrobit životinja okarakterizirati pravnim dobrima, kakav trenutno i jest njihov status u izvorima prava ovog područja.

\section{ZAŠTITA ŽIVOTA, ZDRAVLJA I DOBROBITI ŽIVOTINJE}

\subsection{Izvori prava}

Ustav Republike Hrvatske (NN 56/90, 135/97, 8/98, 113/00, 124/00, 28/01, 41/01, $55 / 01,76 / 10,85 / 10,05 / 14)$ temeljni je pravni akt koji regulira osnovne postavke pravnog i društvenog poretka, no isti akt ne govori previše o zaštiti života, zdravlja i općenito dobrobiti životinja. Naime, u Nacrtu prijedloga Zakona o zaštiti životinja stoji kako je „ustavna osnova za donošenje ovoga Zakona sadržana u odredbi članka 2. stavka 4. podstavaka 1. Ustava Republike Hrvatske gdje se navodi kako Hrvatski sabor ili narod neposredno, samostalno, u skladu s Ustavom i zakonom, odlučuju o očuvanju prirodnog i kulturnog bogatstva i korištenju njime“ (Vlada Republike Hrvatske, 2017b). Na- 
vedena odredba ipak jasno dočarava antropocentrični aspekt koji je još uvijek podosta prisutan u društvu. Osim navedene odredbe, od ključne je važnosti čl. 3. Ustava u kojem se navodi kako su očuvanje prirode i čovjekova okoliša, između ostalog, najveće vrednote ustavnog poretka Republike Hrvatske i temelj za tumačenje Ustava. Republika Hrvatska vlastitim kaznenopravnim sustavom u okviru blanketnih odredbi kaznenog djela ubijanja ili mučenja životinja štiti život te fizički i psihički integritet svake životinje. Pojam blanketnih odredbi označava činjenicu da kazneno zakonodavstvo propisuje samo okvir inkriminacije koja se detaljnije nadopunjuje drugim zakonskim izvorima prava tog kaznenog djela. Tako osim Kaznenog zakona (125/11, 144/12, $56 / 15,61 / 15,101 / 17)^{9}$, osnovni zakonski izvori koji reguliraju pitanje zaštite života i integriteta životinja jesu: Zakon o zaštiti životinja (NN 102/17), Zakon o zaštiti okoliša (NN 80/13, 153/13, 78/15) i Zakon o zaštiti prirode (NN 80/13).

Od izvora europskog prava potrebno je spomenuti i one važnije direktive koje su morale biti implementirane u nacionalno zakonodavstvo: Direktiva o zaštiti životinja koje se koriste za znanstvene svrhe (Europski parlament i Vijeće EU, 2010), Direktiva Vijeća o zaštiti životinja koje se drže u svrhu proizvodnje (Vijeće EU, 1998) i Direktiva o držanju divljih životinja u zoološkim vrtovima (Vijeće EU, 1999). Međunarodni dokumenti koji reguliraju ovo pitanje brojni su te je potrebno spomenuti one važnije unutar Ujedinjenih naroda i Vijeća Europe: Međunarodnu konvenciju za zaštitu ptica (UNEP, 1950), Konvenciju o biološkoj raznovrsnosti (UN, 1992) s oba protokola ${ }^{10}$,Europsku konvenciju o zaštiti životinja u međunarodnom prijevozu (Vijeće Europe, 1968), Bernsku konvenciju o očuvanju europskog divljeg života i prirodnog staništa (Vijeće Europe, 1979), Europsku konvenciju o zaštiti kućnih ljubimaca (Vijeće Europe, 1987), Europsku konvenciju za zaštitu životinja za klanje (Vijeće Europe, 1988) itd.

Visković (1996:473) pravilno navodi kako se, s gledišta pravne tehnike, zaštita životinja može izvesti na tri osnovna načina: a) općim propisima protiv zlostavljanja, i to svih ili samo nekih kategorija, npr. domaćih životinja, kralješnjaka itd. (Zakon o zaštiti životinja); b) propisima o zaštiti prirode (Zakon o zaštiti prirode); c) propisima iz raznih pravnih grana kojima se neke životinje zaštićuju u posebnim pravnim odnosima (Kazneni zakon, Zakon o lovu, Zakon o poljoprivredi, itd.). Njemačka je jedna od država koja upravo na ovaj način, kombinacijom svih ovih tehnika uređuje zaštitu života, zdravlja i dobrobiti životinje (Visković, 1996:473). Komparativno gledajući, ista je situacija i u Republici Hrvatskoj.

Za potrebe ovog rada, u nastavku, ali i kroz cijeli rad, detaljnije će biti analizirana dva glavna izvora prava ovog područja u nas: Zakon o zaštiti životinja te Kazneni zakon, točnije kazneno djelo ubijanja ili mučenja životinja.

9 Dalje u tekstu: KZ.

10 Kartagenski protokol o biološkoj zaštiti (Tajništvo Konvencije o biološkoj raznolikosti, 2000) i protokol Nagoya o pristupu genetskim resursima i poštenoj i pravičnoj podjeli dobiti koja proizlazi iz njihovog korištenja (Tajništvo Konvencije o biološkoj raznolikosti, 2011) 


\subsection{Zakon o zaštiti životinja}

Hrvatska je još 1999 . godine dobila prvi zakon kojim se reguliralo pitanje zaštite života, zdravlja i dobrobiti životinja - Zakon o dobrobiti životinja (NN 19/99). Iako je navedeni zakon u odnosu na trenutni imao gotovo dvostruko manje članaka te regulirao ovo pitanje prilično šturo, bio je početni i veliki korak u zaštiti životinjskog života, zdravlja i dobrobiti općenito u Hrvatskoj. Kako se navedeni zakon pokazao, u pojedinim dijelovima, kao nedostatna osnova za donošenje podzakonskih propisa kojima se štite život, zdravlje i dobrobit životinja u skladu s trenutačno važećim spoznajama, bilo je potrebno donijeti novi zakon u kojem će se takvi nedostaci ispraviti (Vlada Republike Hrvatske, 2017a). Drugi glavni razlog donošenja zakona odnosio se na činjenicu implementacije glavnih izvora prava EU iz područja zaštite životinje u hrvatsko zakonodavstvo.

Zakon o zaštiti životinja (NN 102/17) stupio je na snagu 26. listopada 2017. i sastoji se od trinaest dijelova te ukupno devedeset i osam članaka od kojih, sukladno članku 98., članci 70., 71., 86. stavak 1. točka 8. i članak 90. točke 3., 4. i 5. stupaju na snagu 31. prosinca 2018. Zakon je usklađen s propisima EU, između ostalog i s prethodno navedenim direktivama. Zakon štiti točno određene kategorije životinja: životinje koje se koriste u znanstvene svrhe, životinje koje se uzgajaju i koriste u svrhu proizvodnje, divlje životinje, kućne ljubimce, životinje u zoološkim vrtovima, životinje koje se koriste u cirkuskim predstavama, za filmska i televizijska snimanja, izložbe, smotre, natjecanja, predstave i u druge svrhe s ciljem predstavljanja životinja, napuštene i izgubljene životinje te životinje u trgovinama za prodaju kućnih ljubimaca. Što se tiče područja primjene (čl. 3.), Zakon se primjenjuje na sve životinje kralježnjake te na glavonošce iz razreda Cephalopoda koji se koriste u znanstvene svrhe. ${ }^{11}$ Zakon se ne primjenjuje na gospodarenje lovištem i divljači te ribolov (čl. 3., st. 3. i 4.). Novi zakon donosi upravo one promjene koje se odnose na zaštitu života i zdravlja životinje, a pogotovo u odnosu

11 Još je Visković (1992:287) tvrdio kako najbrojniji dio divljih životinja ostaje nezaštićen, na milost i nemilost ljudi, pogotovo gmazovi, vodozemci i beskralješnjaci. Što se tiče potonjih, na ovu je kontroverznu odredbu Zakona o zaštiti životinja predložen velik broj amandmana kod samog Prijedloga zakona o tome da bi se zakon trebao primjenjivati na sve životinje. Službeni je odgovor Vlade ipak bio nedorečen u određenoj mjeri te je glasio: „Ovaj Zakon se primjenjuje na sve kralježnjake i iznimno na glavonošce iz razreda Cephalopoda koji se koriste u znanstvene svrhe. Ovaj se Zakon ne primjenjuje na ribolov, a drugih korištenja Cephalopoda osim u znanstvene svrhe nema, tako da ni zaštita Cephalopoda kroz ovaj Zakon nema svrhe. Donošenje odredbe da se ovaj Zakon primjenjuje na sve životinje nije razmatrano jer nije predmet normativne aktivnosti kroz ovaj Zakon“. Kontroverzan je navod kako razmatanje primjene zakona na sve životinje nije predmet normativne aktivnosti ovog Zakona jer se upravo i radi o Zakonu koji je glavni izvor zaštite života, zdravlja i dobrobiti životinja kao živih bića te se postavlja pitanje jesu li ostalim zakonima (poglavito Zakonom o zaštiti prirode) nenavedene životinje uistinu pravilno zaštićene te imaju li, prema zakonodavcu, subjektivnim tumačenjem ovih odredbi - određene životinje ipak veći stupanj zaštite od drugih? Ipak Zakon o zaštiti prirode regulira ovo pitanje općenitije štiteći i čuvajući prirodu, njezine sastavne dijelove te ostala pitanja s tim u vezi. Visković (1992:288) tvrdi kako je zaštita životinja u određenim pravnim porecima diskriminatorna i motivirana isključivo ljudskim privrednim, emotivnim, zabavnim, znanstvenim, kulturnim, vjerskim i drugim interesima, a ne brigom za dobro samih životinja kao vrijednosti po sebi. 
na: zabranu neodgovarajućih postupanja prema životinjama (npr. bacanje petardi na životinje, držanje stalno vezanih pasa, držanje divljih životinja u ugostiteljskim objektima i sl.), zaštitu kućnih ljubimaca tijekom njihovog uzgoja, držanja, prometa i prodaje, kontrolu razmnožavanja kućnih ljubimaca (na području na kojem se utvrdi veliki broj napuštenih pasa ministar poljoprivrede određuje način i financiranje kontrole razmnožavanja napuštenih pasa) te evidentiranje vlasnika kućnih ljubimaca namijenjenih prodaji s manje od tri rasplodne ženke iste vrste životinja, radi praćenja prometa i dobrobiti životinja (Ministarstvo poljoprivrede, 2017). Jedna od najvažnijih novosti koja se odnosi upravo na zaštitu života, zdravlja i dobrobiti životinja jest osnivanje tzv. no kill skloništa, točnije zabranjeno je usmrćivanje napuštenih životinja. Prema čl. 62. može se vidjeti velik pomak u zaštiti života, zdravlja i dobrobiti samih životinja te se nalaže kako se na području svake jedinice područne (regionalne) samouprave mora osnovati najmanje jedno sklonište u kojem je osigurano najmanje 50 smještajnih mjesta za životinje, a financiranje snosi svaka jedinica lokalne samouprave u RH.

Bioetički gledano, Jakovljević (2013:171) smatra kako je upravo pravo na život i opstanak u mjeri svojstvenih organskih funkcionalnih mogućnosti održivosti svake životinjske vrste i jedinke, na tjelesnu nepovredivost i sigurnost, tj. neugroženost, osnovno životinjsko pravo koje može biti ugroženo samo u četiri slučaja: kada održavanje određenih životinjskih jedinki odnosno grupa u životu predstavlja veliku opasnost za ostale vrste živih bića; u slučajevima samoobrane čovjeka od životinje; ako su neke životinje nezamjenjiva hrana za ljude kao mesojede te ako usmrćivanje jednih predstavlja uvjet preživljavanja i opstanka, održavanja u životu drugih; unutar situacija kada su određene životinje beznadno oboljele ili teško, nepopravljivo povrijeđene, paralizirane itd., te kada, dakle, njihovo daljnje održavanje na životu predstavlja samo produljenje mučne agonije i dalje umnožavanje njihovih intenzivnih patnji. Potrebno je naglasiti kako je novi Zakon o zaštiti životinja implementirao sve navedeno, čak još i detaljnije pa je čl. 11. (NN 102/17) taksativno predviđeno sedamnaest slučajeva kada je životinju moguće usmrtiti i pod kojim uvjetima. ${ }^{12}$

$\mathrm{Na}$ kraju zakona nalazi se velik broj prekršajnih odredbi koji dovedeni u kontekst $s$ kaznenim djelom ubijanja ili mučenja životinja mogu izazvati prilično kontroverzna pravna pitanja. Primjerice, novčanom kaznom može se kazniti osoba koja organizira

12 Tako je potrebno naglasiti kako i zabrana usmrćivanja u skloništima bez ubijanja nije apsolutna te je, prema čl. 65. (NN 102/17), usmrćivanje moguće ako: 1) bi liječenje životinja bilo dugotrajno i povezano s patnjama, a ishod liječenja neizvjestan; 2) je životinja dostigla visoku starost te joj otkazuju osnovne životne funkcije; 3) životinja boluje od neizlječive bolesti; 4) je takav postupak prijeko potreban zbog provođenja mjera kontrole bolesti u skladu s posebnim propisima iz područja veterinarstva, posebno onih koje mogu ugroziti ljude ili nanijeti velike gospodarske štete; 5) se takav postupak provodi u svrhu zaštite zdravlja i sigurnosti ljudi i životinja te zaštite imovine; 6) je takav postupak potreban za provedbu članaka gdje se nalaže da se divlja životinja može usmrtiti ako se ne može smjestiti u sklonište, a lovoovlaštenik ili zoološki vrt nisu životinju u mogućnosti primiti i u slučaju zatvaranja zoološkog vrta ili nekog njegovog dijela koji ne udovoljavaju zakonskim uvjetima; 7) životinja trpi jaku i neotklonjivu bol; 8) je razlog dobrobit životinje; 9) je životinja opasna za okolinu; 
utrke pasa, baca petarde na životinje ili recimo spolno opći sa životinjom. S tim u vezi može se postaviti pitanje ne bi li se iste radnje mogle okarakterizirati upravo kao kazneno djelo ubijanja ili mučenja životinja te je li eventualno moguće odgovarati za navedeni prekršaj i za navedeno kazneno djelo istodobno? Ovdje se radi o temeljnim pitanjima pravnog načela ne bis in idem ${ }^{13}$. Samim time, glavni kriteriji pri tome je li osoba nepravedno osuđena i za prekršaj i za kazneno djelo jesu: definiranje zaštićenog dobra kod oba prijestupa (što je zakonodavac odredio kao zaštitni subjekt / objekt) i nastupjela posljedica, odnosno njena težina (Đuras, 2016:227). Radi zaštite interesa žrtve i oštećenika ne može se ignorirati nastupanje teže posljedice koja je pretpostavka za počinjenje kaznenog djela (Đuras, 2016:227). Naime, upravo se najčešće zbog nastupa teških posljedica - tjelesnih ozljeda, materijalnih šteta, smrti, širenja zaraznih bolesti i slično, kazneno djelo po značaju zaštitnog objekta (subjekta) izdiže iznad sfere prekršajnog koji je po svojoj pravnoj prirodi blaže naravi (Đuras, 2016:227).

Potrebno je pohvaliti intenciju zakonodavca da prilično detaljno odredi ovako veliki opseg prekršaja u Zakonu o zaštiti životinja, stavljajući u sferu kaznenog djela samo slučajeve $s$ težom posljedicom jer je razlika između kaznenog djela i prekršaja upravo kvantitativne naravi. U tom pogledu, odredbe Kaznenog zakona u svojoj ideji trebale bi biti tzv. ultima ratio (lat. krajnje sredstvo) u rješavanju određenih delikata u društvu, pa je stoga prilično nezamislivo da Kazneni zakon za svako kazneno djelo sadrži ovako detaljan opseg kao što je slučaj s prekršajima u Zakonu o zaštiti životinja. Bit je u tome da prekršaji iz Zakona o zaštiti životinja ne ispunjavaju biće kaznenog djela ubijanja ili mučenja životinje.

\subsection{Kazneno djelo ubijanja ili mučenja životinja}

Ubijanje ili mučenje životinja kazneno je djelo protiv okoliša. Intencija je zakonodavca da ide u korak s vremenom, sprječavajući sve one radnje koje su uglavnom vezane uz eksploataciju okoliša na njegovu štetu, iako se vrlo često postavlja pitanje koliko su određeni pravni instituti primjenjivi kod ovih kaznenih djela te ako i jesu u kojoj su mjeri primjenjivi. Tako je, primjerice, znanstveno već razrađivano kontroverzno pitanje o primjenjivosti nužne obrane kod kaznenog djela ubijanja ili mučenja životinja.

Prema Ascioneu (1993:28) mučenje životinja definira se kao društveno neprihvatljivo ponašanje koje uključuje namjeru nanošenja nepotrebne boli, patnje, neugode i / ili smrti životinji (tako i Horvat, 2011:84). Kazneno djelo ubijanja ili mučenja životinja regulirano je člankom 205. KZ-a gdje je za temeljni oblik kaznenog djela predviđeno

13 Pravno načelo ne bis in idem (lat. ne dvaput o istom) temeljno je procesnopravno načelo po kojem je zabranjeno dva puta suditi o istoj stvari. U praksi i teoriji velike su dvojbe može li se istodobno suditi i za prekršaj i kazneno djelo. U presudi Engel i drugi protiv Nizozemske (1976) Europski sud je naveo tri kriterija koja se pri tom moraju uzeti u obzir: 1. Je li prva kazna po svojoj naravi bila kaznenopravna?, 2. Jesu li djela radi kojih se podnositelj zahtjeva kazneno goni ista (idem)? i 3. Je li postojala dvostrukost postupka (bis)? (Đuras, 2016:226). Ovo je pitanje u RH došlo do izražaja presudama Maresti protiv Hrvatske (2009) i Tomasović protiv Hrvatske (2011) Europskog suda za ljudska prava (Đuras, 2016). 
da će se kaznom zatvora do jedne godine kazniti ona osoba koja usmrti životinju bez opravdanog razloga ili je teško zlostavlja, nanosi joj nepotrebne boli ili je izlaže nepotrebnim patnjama. Traži se postupanje s izravnom namjerom, no u literaturi još uvijek postoje dvojbe može li djelo biti počinjeno is neizravnom namjerom. Prema Turković i sur. (2013:278), djelo mora biti počinjeno s izravnom namjerom, a ako takva namjera ne postoji, može se raditi o prekršaju. Prema Pavloviću (2015:919), neprihvatljivo je stajalište da djelo mora biti počinjeno $s$ izravnom namjerom jer nije teško zamisliti situaciju u kojoj je netko svjestan da svojom radnjom može bez opravdanog razloga usmrtiti životinju ili joj nanijeti nepotrebne boli ili je izložiti nepotrebnim patnjama ili je zlostavljati pa unatoč tome na to pristaje. Sukladno navedenom, potrebno je naglasiti kako će se u praksi kod ovog kaznenog djela uglavnom pojavljivati izravna namjera, ali time nije isključena ni mogućnost počiniteljeva postupanja s neizravnom namjerom (Nedić, 2017:781). Kvalificirani oblik predviđen je stavkom 2. gdje će se kazniti do dvije godine zatvora ona osoba koja kazneno djelo počini iz koristoljublja čime je kazna povećana s kazne zatvora do jedne godine na kaznu zatvora do dvije godine. Stavak treći predvida i nehajnu odgovornost gdje će se osoba koja nehajem uskratom hrane ili vode ili na drugi način izloži životinju tegobnom stanju kroz dulje vrijeme, kazniti kaznom zatvora do šest mjeseci. Novost je odredba iz stavka 4. da se zlostavljana životinja, koja preživi zlostavljanje, oduzima zlostavljaču čime je učinjen veliki pozitivan korak u zaštiti životinja jer se dosad, zbog nepostojanja zakonske regulative, zlostavljana životinja, nakon oporavka od ozljeda i pružene veterinarske pomoći, vraćala zlostavljaču (Ius-info, 2013). Djelo je, s obzirom na počinitelja, koncipirano kao delictum communium, može ga počiniti svatko, neovisno o vlasništvu ili posjedu nad životinjom, a također dolazi u obzir i odgovornost pravnih osoba za ovo kazneno djelo, napose glede nehajnog oblika (Novoselec, 2011:285). Zbog blanketne prirode odredbi KZ-a, ovdje dolazi u obzir primjena Zakona o zaštiti okoliša, Zakona o zaštiti životinja te Zakona o zaštiti prirode. Bitno je naglasiti kako usmrćivanje iz navedenog kaznenog djela mora biti bez opravdanog razloga. Neopravdani razlog bio bi, npr. prema Zakonu o zaštiti životinja - slučaj omamljivanja, klanja ili usmrćivanja životinje u ritualne svrhe, u svrhu proizvodnje krzna, isto i usmrćivanje pasa i mačaka u svrhu proizvodnje hrane i drugih proizvoda, itd. Potrebno je istaknuti kako različiti narodni običaji koji u sebi uključuju bilo koji oblik nasilnog ponašanja prema životinji ne isključuju činjenje prekršaja ili eventualno kaznenog djela. U tom je pogledu potrebno razlikovati običajno pravo od običaja koji nisu od pravne važnosti i ne čine izvor prava (Vrban, 2003:352). Tako je i u hrvatskoj sudskoj praksi (Županijski sud u Splitu, Kž-372/07 od 12. rujna 2007., Općinski sud u Sinju, K-118/06), sud zauzeo stajalište po kojem je zaštita života i integriteta životinje važnija od narodnog običaja. Tako su okrivljenici koji su vezali pijetlove konopcem na livadi i pritom ih iz daljine gađali mecima iz pištolja osuđeni na novčanu kaznu. Sud je tvrdio kako „se takvo ponašanje ne može opravdati narodnim običajem jer pravni poredak i civilizirano društvo ne toleriraju običaje kojima se krše norme kaznenog prava, odnosno u konkretnom slučaju ostvaruju obilježja kaznenog djela mučenja životinja. Takvi narodni običaji ne isključuju postojanje kaznenog djela, a ni kaznenu odgovor- 
nost okrivljenika“. Kod istog je predmeta također zanimljivo pitanje neotklonjivosti ili otklonjivosti zablude o protupravnosti djela, no istim se pitanjem sud i obrana nisu bavili što ipak predstavlja svojevrstan kaznenopravni dogmatski propust (više u: Novoselec, 2007:1032).

Slučajevi zlostavljanja životinja u Hrvatskoj pojavljuju se sve više. No, velik broj počinitelja ipak ostaje neprocesuiran pa se u praksi hrvatskih sudova ne pojavljuje ni približno toliko slučajeva koliko imamo prilike čitati u medijima. Razlog tome vrlo vjerojatno je i činjenica da ne postoji dovoljno velika svijest o pravilnom suživotu čovjeka i životinje, kao i to da vlada shvaćanje životinja kao nižih bića bez prava i subjektiviteta (više u: Horvat, 2011:83). I sam Visković (2009:394) postavlja pitanje koje autori, baveći se ovom tematikom često citiraju: „kako spriječiti nepravedno upadanje prava jednih bića u prava drugih bića, tj. razornu apsolutizaciju ičijih prava?" Jedan od odgovora može ležati i u kaznenopravnom institutu nužne obrane. Sukladno tome, u stranoj i domaćoj kaznenopravnoj teoriji napravljena su zanimljiva teorijska razmatranja može li institut nužne obrane biti primjenjiv kod kaznenog djela ubijanja ili mučenja životinja u smislu da pomagač odbije istodobni ili izravno predstojeći protupravni napad napadača od same životinje. U tuzemnom istraživanju (Nedić, 2017) naveden je hipotetski primjer. Ako slučajni prolaznik uoči da dvije osobe zlostavljaju mačku stavljajući joj pirotehničke naprave u usta koje namjeravaju zapaliti, moguće je da će htjeti reagirati da ih zaustavi u tome i da će morati upotrijebiti i određenu silu da spriječi napadače. Ako bi u ovom slučaju isključili primjenu nužne obrane, tada bi eventualni počinitelj mogao odgovarati za nanošenje (lakih) tjelesnih ozljeda napadačima na životinju, što nije sasvim ispravna kvalifikacija jer je imao za namjeru pomoći životinji koja je inferiorna napadačima i jer je takvim ponašanjem namjeravao spriječiti počinjenje kaznenog djela. Navodeći točno utvrđene teorijske i empirijske kaznenopravne činjenice, istraživanje je pokazalo kako se istodobni ili izravno predstojeći protupravni napad na životinju kojim se ugrožava njezin život ili zdravlje može odbijati nužnom obrambenom radnjom (više u: Nedić, 2017). Radi sprječavanja posljedica potrebna je hitna reakcija, a ona je moguća kroz primjenu nužne obrane. Navedenim činom slučajnog prolaznika uistinu se zaštićuje pravo u odnosu na nepravo što je jedan od temeljnih načela instituta nužne obrane. Do izražaja dolazi i solidarnost čovjeka prema životinji u teškoj situaciji, ali i općenito se podiže čovjekova svijest pravilnog i nenasilnog suživota sa životinjama kao živim bićima.

\subsection{Cilj zaštite - zaštita života, zdravlja i dobrobiti životinja ili zaštita društvenog poretka od nečovječnog postupanja}

Jedno od bitnijih pitanja koje se postavlja također jest, štiti li pravni poredak inkriminacijom ponašanja ubijanja ili mučenja životinja život životinje neposredno ili posredno, odnosno štiti li pravni poredak isključivo život, zdravlje i dobrobit životinje (neposredna zaštita života i zdravlja) ili se prije svega štiti cjelokupni društveni poredak zabranom bilo kakvog nasilnog i za društvo nepoželjnog ponašanja (posredna zaštita života i zdravlja životinje). Npr. ako uzmemo u obzir kako u KZ-u postoji kazneno djelo oštećenja tuđe stvari, već spomenutim kriterijem neposredne zaštite, možemo doći do pomalo ba- 
nalnog zaključka kako se istom inkriminacijom isključivo štiti tjelesna cjelovitost stvari kao onoga što nije živo biće. U ovom pogledu do izražaja dolazi bioetičko pitanje koje se ogleda u konfrontaciji između antropocentrične i biocentrične etike, odnosno štiti li se pravnim sustavom isključivo život, zdravlje i dobrobit životinja kao bića u vidu biocentrizma ili pak, antropocentrično gledajući, cjelokupni društveni sustav od nasilnog ponašanja u vidu zabrane istog kako ono ne bi, potencijalno, eskaliralo pogubno za čovjeka u bilo kojem smislu?

Pravno dobro treba razlikovati od objekta radnje jer pravno je dobro, kao vrijednost na kojoj počiva sigurnost društva, idealne naravi, dok je objekt radnje realni, individualizirani predmet na kojem se izvršava radnja. Kod ubojstva je pravno dobro život čovjeka uopće, a objekt radnje konkretan čovjek koji se ubija, pa se prema tome pravno dobro uvijek povređuje posredno, putem napada na objekt radnje (Novoselec i Bojanić, 2013:128). MacCormick (2014) tvrdi kako je odredivanje toga tko je korisnik zakona, a što tek sredstvo za postizanje nekoga daljnjeg vjerojatnog dobra, stvar tumačenja i prosudbe. On u tom pogledu tvrdi kako možemo biti sigurni da zakon koji zabranjuje rušenje povijesnih zgrada ima za svoj vjerojatan cilj promicanje kulturnih interesa ljudi, a ne fizičku cjelovitost zgrada te je ovo potonje tek sredstvo za postizanje opravdavajućega cilja zakona (MacCormick, 2014:128). Slučaj zakona koji zabranjuju okrutno postupanje prema životinjama u tome je pogledu prijeporan slučaj, jer dok je prema nekima on u prvome redu opravdan kao zaštita ljudskoga interesa u čovječnu postupanju, prema drugima je on u prvome redu opravdan kao zaštita životinja od bezrazložno nanesene patnje (MacCormick, 2014:128). MacCormick (2014) govori o kriteriju trpljenja (tzv. čista pasivna sposobnost) gdje smatra da svaka ozljeda, šteta ili gubitak pretrpljen kao dovoljno predvidiva ili „,neposredna“ posljedica dotične povrede daje temelj prvozaštitnu subjektivnu pravu u korist oštećenika. U svrhu rješavanja toga pitanja od najveće je važnosti imati stajalište o tome uključuje li, načelno, ili može li, načelno, počinjenje zakonom kažnjiva djela uključivati povređivanje, odnosno počinjenje delikta protiv nekoga drugog bića, što pak zahtijeva da dotični entitet ima sposobnost trpjeti pravne delikte (MacCormick, 2014:128). On, u danome slučaju, mora biti i članom skupine čija je stvarna zakonska zaštita među opravdavajućim ciljevima dotična zakona (MacCormick, 2014:128). U tom pogledu, cilj Zakona o zaštititi životinja jest zaštita njihova života, zdravlja i dobrobiti, ${ }_{14}^{14}$ što nesumnjivo dovodi do zaključka kako se i blanketnim odredbama kaznenog djela ubijanja ili mučenja životinja u prvom redu štiti upravo život, zdravlje i dobrobit životinje.

14 Članak 1. Zakona o zaštiti životinja glasi: „Ovim se Zakonom propisuje odgovornost i obveze fizičkih i pravnih osoba radi zaštite životinja tijekom korištenja, što uključuje zaštitu njihova života, zdravlja i dobrobiti, način postupanja sa životinjama, uvjeti koji su potrebni za zaštitu životinja pri držanju, uzgoju, izvođenju zahvata na životinjama, usmrćivanju, prijevozu, korištenju životinja u znanstvene svrhe, držanju životinja u zoološkim vrtovima, u cirkusima i drugim predstavama, prilikom prodaje kućnih ljubimaca te postupanje s napuštenim i izgubljenim životinjama, inspekcijski nadzor i prekršajne odredbe“ (NN 102/17). 
Osim MacCormicka, i Singer (1998) također navodi osjećaj patnje životinje kao glavni kriterij prava na zaštitu prema načelu jednakosti koje zahtijeva da se njezina patnja uzme u obzir jednako kao i slična patnja bilo kojeg drugog bića. Po njemu nije pitanje mogu li životinje rasuđivati niti govoriti, nego isključivo mogu li patiti (Singer, 1998:6). Ako neko biće pati, onda ne može postojati nikakvo moralno opravdanje za odbijanje da se ta patnja uzme u obzir (Singer, 1998:7). Tako limit sposobnosti za osjećanje jest jedina branjiva granica za brigu o interesima drugih (Singer, 1998:7). Dieter Birnbacher također zastupa sposobnost patnje kao granicu ljudske dužnosti prema životinjama, a ta granica su visoke životinje (Cifrić, 2007:7).

Ovo pitanje može se smatrati nepotrebnim i u smislu da je prije svega bit da se zaštiti životinja kao biće, bez obzira štiti li se ona tek posredno ili neposredno. No, ovo pitanje može itekako doći do izražaja kod određenih pravnih instituta gdje je itekako bitno razmotriti štiti li se ovdje život, zdravlje i dobrobit životinje posredno ili neposredno. U navedenim istraživanjima primjenjivosti nužne obrane kod kaznenog djela ubijanja ili mučenja životinja (Nedić, 2017) navodi se kako se u njemačkoj kaznenopravnoj literaturi (Schönke i Schröder, 2010; Jähnke i sur., 2003) zastupa i zanimljivo stajalište kako bi uporaba sile pomagača koji pomaže napadnutoj životinji prema napadaču uistinu mogla biti opravdana nužnom obranom jer se „ljudska samilost prema mučenoj životinji može braniti“. Iz navedenog proizlazi kako se u prvom redu radi o zaštiti ljudskih osjećaja prema životinji, a ne o zaštiti života i zdravlja životinje. Kantova teorija dužnosti sućuti prema životinjama, ili barem prema nekima od njih, također je izraz relativnog isključenja, jer je takav obzir spram životinja tek obzir spram osjećajnosti čovjeka, a ne obzir spram životinje kao autonomne vrijednosti (Visković, 1996:397). Određeni su kaznenopravni autori u Njemačkoj preciznije obradili navedeno stajalište i stvorili novo. Tako Roxin (2006) zastupa stajalište kako se nužnom obranom može štititi i pravna osoba ili embrij i da stoga ništa ne stoji na putu tumačenja da se i život životinje može braniti nužnom obranom u vidu odbijanja protupravnog napada od drugoga. Takvo stajalište implicira da su život, zdravlje i dobrobit životinje zaštićena pravna dobra jer polazi od zaštite ,života i zdravlja životinja“ koja se izričito ističe u članku 1. njemačkoga Zakona o zaštiti životinja (njem. Tierschutzgesetz) (Nedić, 2017:792).

Potrebno je, prije svega, kao polaznu točku uzeti Ustav RH koji očuvanje prirode i čovjekova okoliša svrstava u temeljne vrednote ustavnog poretka Republike Hrvatske. Osim toga, treba uzeti u obzir i cilj donošenja i postojanja Zakona o zaštiti životinja, ali i Zakona o zaštiti prirode. Kako su odredbe kaznenog djela ubijanja ili mučenja životinja blanketne prirode i nadopunjuju se isključivo navedenim zakonima, tada možemo slobodno reći kako ustavnopravni i kaznenopravni poredak štite život, zdravlje i dobrobit životinja kao pravna dobra. Navedeni osjećaji i samilost prema životinjama zasigurno su bili ključni za reguliranje kaznenog djela ubijanja ili mučenja životinja te donošenje Zakona o zaštititi životinja, no glavni je razlog zasigurno bioetičke prirode, a odnosi se na jamstvo zaštite života, zdravlja i dobrobiti životinja, solidarnosti čovjeka prema životinji te regulaciju suživota između čovjeka i životinje. Uz to, u hrvatskoj kaznenopravnoj literaturi, još u vrijeme kada je kazneno djelo mučenja životinje po prvi puta regulirano 
KZ-om, zauzeto je stajalište kako se takvom inkriminacijom zaštićuje dobrobit životinja (Novoselec, 2011:285). Što se tiče primjera s kaznenim djelom oštećenja tuđe stvari, potrebno je reći kako ovdje pravni poredak prije svega štiti imovinu, ${ }^{15}$ odnosno čovjekovo pravo na vlasništvo, točnije čovjeka kao subjekta prava, pa i sama pomisao da se neposredno štiti stvar definitivno nije pravno utemeljena, pogotovo ako u obzir uzmemo već navedenu teoriju trpljenja.

Nesumnjivo je kako KZ kaznenim djelom ubijanja ili mučenja životinja štiti i cjelokupni društveni i pravni poredak od bilo kakvog nasilnog i za društvo nepoželjnog ponašanja. U navedenim istraživanjima nužne obrane kod kaznenog djela ubijanja ili mučenja životinja jasno se vidi kako se nužnom obranom štiti i život životinje, ali je nedvojbeno da se time istodobno štiti i pravni i društveni poredak, što se ogleda u jednom od temeljnih postulata nužne obrane, a to je afirmacija prava u odnosu na nepravo.

Primarni je cilj navedene odredbe neposredna zaštita života, zdravlja i dobrobiti životinja, a taj zaključak proizlazi iz blanketnih odredbi KZ-a i donošenja te postojanja Zakona o zaštiti životinja i Zakona o zaštiti prirode. Takav je zaključak bitan jer jasno izražava kako cjelokupni pravni poredak RH jamči zaštitu života, zdravlja i dobrobiti životinja kao pravnih dobara.

\section{ZAKLJUČNA RAZMATRANJA}

Kvalitetan i učinkovit pravni sustav glavni je preduvjet funkcioniranja bilo koje pravne države u kojoj dominira vladavina prava te stabilno društvo. Tako je i kod pravilnog funkcioniranja suživota čovjeka i životinje, gdje se prije svega zahtijeva izgradnja kvalitetnog i učinkovitog pravnog sustava koji jamči životinjama zaštitu njihova života, zdravlja i dobrobiti. Upravo to i jest cilj prava životinja, kao pravne grane, koje pravno utemeljeno egzistira s ciljem zaštite navedenih elemenata u vidu pravilnog ophođenja ljudi sa životinjama, kao živih bića poput ljudi.

Povijesna metoda pokazala je kako je pravni status objektiviteta životinja uspostavljen još rimskim privatnim pravom te da je pitanje životinjskog subjektiviteta tek nedavno otvoreno. Potrebno je napomenuti kako se životinje, načelno gledajući, još uvijek smatraju objektima prava, premda postoje situacije (npr. spomenuti sisavci u vojsci) gdje je uistinu upitno je li takva kategorizacija u potpunosti ispravna. No, osim navedenih situacija u praksi, ali i brojnih pravnih istraživanja, zamjetna je tendencija da se takav status životinje promijeni, što se poglavito odnosi na spomenutu odredbu njemačkog Građanskog zakonika. Uz to, pitanje mogu li životinje imati subjektivna prava jest pitanje u kojem se postavlja još mnogo zasebnih pravnoteorijskih pitanja, koja su navedena u radu te za koja još uvijek ne postoji univerzalno znanstveno rješenje, ali i ono pitanje na kojem se aktivno radi u krugovima znanstvenika iz područja teorije prava. Glavna pitanja, u tom smislu, koja je ovaj rad iznjedrio su: mogu li životinje biti subjektima

15 U tom smislu, kazneno djelo oštećenja tuđe stvari spada u kaznena djela protiv imovine. 
prava, mogu li biti nositeljima prava bez dužnosti, iako nisu subjekti prava, te ako bi životinje i bile smatrane subjektima prava mogu li ljudi i dalje imati vlasništvo nad njima. Jedno od rješenja koje se predlaže jest modificirani subjektivitet životinja uz imenovanje određenih ljudi zakonskim zastupnicima životinja, ali i takvo rješenje sa sobom nosi mnogobrojna kontroverzna pitanja.

Valja istaknuti da se rezultat istraživanja prije svega očituje u tome da su život, zdravlje i dobrobit životinja pravna dobra, zaštićena Ustavom RH, međunarodnim konvencijama, Zakonom o zaštiti životinja, Zakonom o zaštiti prirode te Kaznenim zakonom u vidu kaznenog djela ubijanja ili mučenja životinja. Takav sustav zaštite, komparativno razmatrani, sličan je onom njemačkom, kojem su hrvatska pravna tradicija i pozitivno pravno itekako naklonjene. Potrebno je također naglasiti, kako pravni sustav, biocentrično, štiti život, zdravlje i dobrobit životinja u prvom planu, ne štiteći time osjećaje i samilost ljudi prema životinjama ili pak cjelokupni društveni i pravni sustav u prvom planu od nasilnog ponašanja pogubnog za čovjeka u svakom smislu, iako se zasigurno radi o razlozima koji su potaknuli zakonodavca na zaštitu integriteta životinja. Zakon o zaštiti životinja, u nas je, do sada najdetaljnije koncipiran od svih zakona ovog područja, jer nudi pojačanu zaštitu života, zdravlja i dobrobiti životinja. S tim u vezi treba posebno spomenuti novine vezane uz osnivanje tzv. no kill skloništa te više propisanih prekršaja za bilo koji oblik povrede životinjskog integriteta. U kaznenopravnim okvirima još uvijek je upitno koliko su određeni kaznenopravni instituti primjenjivi kod kaznenog djela ubijanja ili mučenja životinja. Istraživanje primjenjivosti nužne obrane u vezi s navedenim kaznenim djelom pokazuje da se i na tom području pojavljuje povećan interes znanstvenika koji se bave kaznenopravnom dogmatikom.

Kako vrijeme odmiče, ljudska svijest o pravilnom suživotu s ostalim živim svijetom sve više raste. Pravni sustav zaštite života, zdravlja i dobrobiti životinja u Hrvatskoj je razvijeniji nego prije te je potrebno dati vremena da se taj sustav uklopi u hrvatsko društvo i prilike, pogotovo odredbe novog Zakona o zaštiti životinja. Ljudska solidarnost prema životinjama i pravilan suživot vode do izgradnje jednog novog i modernog pravnog sustava koji nije okrenut isključivo čovjeku, nego očuvanju cjelokupnog živog svijeta i prirode koji su neodvojivi dio ljudskog habitusa. 


\section{LITERATURA}

Adams, W. A. (2009). Human subjects and animal objects: Animals as "other" in the law. Journal of Animal Law and Ethics, 3: 29-51.

Ascione, F. R. (1993). Children who are cruel to animals: A review of research and implications for developmental psychopathology. Anthrozoös, 6(4): 226-247.

Ascione, F. R. i Lockwood, R. (2001). Cruelty to animals: Changing psychological, social, and legislative perspectives. U: Salem, D. J. i Rowan, A. N. (ur.), The state of the animals (str. 39-53). Washington, DC: Humane Society Press.

Bürgerliches Gesetzbuch (1896). (BGBl. I S. 42, 2909; 2003 I S. 738), (BGBl. I S. 2787)

Cifrić, I. (2007). Pravo životinjskih vrsta na život. Sociologija i prostor, 45 (1): 3-27.

Čović, A. (2004). Etika i bioetika: Razmišljanja na pragu bioetičke epohe. Zagreb: Pergamena.

DeGrazia, D. (2002). Animal Rigts: A very short introduction. New York: Oxford University Press.

Đuras, I. (2016). Dvostrukost u kaznenom i prekršajnom postupku, Policijska sigurnost, 25(3): 217-228.

Europski parlament i Vijeće Europske unije (2010). Direktiva 2010/63/EU o zaštiti životinja koje se koriste za znanstvene svrhe. Službeni list Europske unije, 276(33): 82-128. Strasbourg, 22.09.2010.

Hewson, C. J. (2003). What is animal welfare? Common definitions and their practical consequences. Canadian Veterinary Journal, 44(6): 496-499.

Horvat, M. (2011). Povezanost mučenja životinja s međuljudskim nasiljem. Kriminologija i socijalna integracija, 19(1): 83-98.

Horvat, M. (2008). Rimsko pravo. Zagreb: Pravni fakultet Sveučilišta u Zagrebu.

Ius-info (2013). Novi Kazneni zakon: usmrćivanje životinja kazneno djelo. URL: http:// www.iusinfo.hr/DailyContent/News.aspx?id=14566 (07.06.2016.)

Jähnke, B., Laufhütte, H. W. i Odersky, W. (ur.) (2003). Strafgesetzbuch, Leipziger Kommentar, Großkommentar. Drugi svezak. Berlin: De Gruyter Recht.

Jakovljević, D. (2013). Prava za životinje. Filozofska istraživanja, 33(1): 167-182.

Kazneni zakon, Narodne novine, 125/11, 144/12, 56/15, 61/15, 101/17.

Kalshoven, F. i Zegveld, L. (2011). Constraints on the Waging of War. Cambridge: Cambridge University Press, .

Kramer, M. H. (2001). Do Animals and Dead People have legal rights. Canadian Journal of Law and Jurisprudence, 29-54.

Krizmanić, M. (2016). O životinjama i njihovim ljudima. Zagreb: V.B.Z.

Freeman, M. D. A. (2008). Lloyd's Introduction to Jurisprudence. London: Sweet and Maxwell / Tomson Reuters.

MacCormick, N. (2014). Institucije prava - ogled iz teorije prava. Zagreb: Naklada Breza. 
Ministarstvo poljoprivrede (2017). Nakon više od 10 godina Hrvatska dobiva novi zakon o zaštiti životinja. URL: http://www.mps.hr/hr/novosti/nakon-vise-od-10-godina-hrvatska-dobiva-novi-zakon-o-zastiti-zivotinja1 (25.11.2017.)

Nedić, T. (2017). Primjenjivost nužne obrane kod kaznenog djela mučenja ili ubijanja životinje. Zbornik Pravnog fakulteta Sveučilišta u Rijeci, 38(2): 779-798.

Novoselec, P. (2004). Sudska praksa. Hrvatski ljetopis za kazneno pravo i praksu, 11(1): 279-284.

Novoselec, P. (2007). Sudska praksa. Hrvatski ljetopis za kazneno pravo i praksu, 14(2): 1031-1036.

Novoselec, P. (ur.) (2011). Posebni dio kaznenog prava. Zagreb: Pravni fakultet Sveučilišta u Zagrebu.

Novoselec, P. i Bojanić, I. (2013). Opći dio kaznenog prava. Zagreb: Pravni fakultet Sveučilišta u Zagrebu.

Pavlović, Š. (2015). Kazneni zakon. Zakonski tekst, komentari, sudska praksa, pravna teorija. Rijeka: Libertin.

Payson Evans, E. (2014). Životinje pred sudom - kazneni progon i smrtna kazna za životinje, Zagreb: Tim press,.

Regan, T. (1983). The Case for Animal Rights. Berkley: University of California Press.

Romac, A. (1983). Rječnik rimskog prava. Zagreb: Informator.

Roxin, C. (2006). Strafrecht, Allgemeiner Teil. Prvi svezak. München: Verlag C. H. Beck.

Sassòli, M., Bouvier, A. i Quintin, A. (2011). How does Law protect in War? Outline of International Humanitarian Law. Volume 1. Geneva: International Committee of the Red Cross.

Schönke, A. i Schröder, H. (2010). Strafgesetzbuch: Kommentar. München: Verlag C. H. Beck.

Singer, P. (1998). Oslobodenje životinja. Zagreb: Ibis grafika.

Stojanović, N. (2017). Pravo životinja. Niš: Pravni fakultet Univerziteta u Nišu.

Stojčević, D. i Romac, A. (1971). Dicta et regulae iuris - Latinska pravna pravila, izreke $i$ definicije sa prevodom i objašnjenima. Beograd: Savremena administracija.

Tajništvo Konvencije o biološkoj raznolikosti (2000). Cartagena Protocol on Biosafety to the Convention on Biological Diversity. Montreal: Tajništvo Konvencije o biološkoj raznolikosti.

Tajništvo Konvencije o biološkoj raznolikosti (2011). Nagoya Protocol on Access to Genetic Resources and the Fair and Equitable Sharing of Benefits Arising from their Utilization to the Convention on Biological Diversity. Montreal: Tajništvo Konvencije o biološkoj raznolikosti.

The Marine Mammal Protection Act of 1972, Public law, 92-522. Amended through Public Law 109-479.

Tucak, I. (2017). Hohfeldova analitička teorija prava. Osijek: Pravni fakultet Sveučilišta Josipa Jurja Strossmayera u Osijeku. 
Turković, K., Novoselec, P., Grozdanić, V., Kurtović Mišić, A., Derenčinović, D., Bojanić, I., Munivrana Vajda, M., Mrčela, M., Nola, S. Roksandić Vidlička, S., Tripalo, D. i Maršavelski, A. (2013). Komentar Kaznenog zakona. Zagreb: Narodne novine. Ujedinjeni narodi (1992). Konvencija o biološkoj raznovrsnosti. Rio de Janeiro, 05.06.1992. Ujedinjeni narodi - Program za okoliš (UNEP) (1950). Međunarodna konvencija za zaštitu ptica. Pariz, 18.10.1950.

Ustav Republike Hrvatske, Narodne novine, 56/90, 135/97, 8/98, 113/00, 124/00, 28/01, 41/01, 55/01, 76/10, 85/10, 05/14.

Verri, P. (1992). Dictionary of the International Law of Armed Conflict. Geneva: International Committee of the Red Cross.

Vidaković Mukić, M. (2006). Opći pravni rječnik. Zagreb: Narodne novine.

Vijeće Europe (1968). Europska konvencija o zaštiti životinja u međunarodnom prijevozu. Serija europskih medunarodnih ugovora, No. 65. Pariz, 13.07.1968.

Vijeće Europe (1979). Konvencija o očuvanju europskog divljeg života i prirodnog staništa. Serija europskih medunarodnih ugovora, No. 104. Bern, 19.09.1979.

Vijeće Europe (1987). Europska konvencija o zaštiti kućnih ljubimaca. Serija europskih medunarodnih ugovora, No. 125. Strasbourg, 13.11.1987.

Vijeće Europe (1988). Europska konvencija za zaštitu životinja za klanje. Službeni list Europske unije, 137(25): 51-52. Bruxelles, 16.05.1988.

Vijeće Europske unije (1998). Direktiva 98/58/EZ o zaštiti životinja koje se drže u svrhu proizvodnje. Službeni list Europske unije, 221(23): 79-83. Luxembourg, 20.07.1998.

Vijeće Europske unije (1999). Direktiva 1999/22/EZ o držanju divljih životinja u zoološkim vrtovima. Službeni list Europske unije, 94(24): 74-76. Bruxelles, 29.03.1999.

Visković, N. (2009). Kulturna zoologija: Što je životinja čovjeku i što je čovjek životinji. Zagreb: Naklada Jesenski i Turk.

Visković, N. (1992). Međunarodna pravna zaštita životinja. Socijalna ekologija, 1(3): 287-296.

Visković, N. (2001). Teorija države i prava. Zagreb: Birotehnika.

Visković, N. (1996). Životinja i čovjek: Prilog kulturnoj zoologiji. Split: Književni krug.

Vlada Republike Hrvatske (2017). Konačni prijedlog Zakona o zaštiti životinja, Zagreb, rujan 2017.

Vlada Republike Hrvatske (2017). Nacrt prijedloga Zakona o zaštiti životinja, Zagreb, svibanj 2017.

Vrban, D. (2003). Država i pravo. Zagreb: Golden Marketing.

Wellman, C. (1997). An Approach to Rights: Studies in the Philosophy of Law and Morals. Dordrecht: Kluwer Academic Publishers.

White, A. (1984). Rights. Oxford: Clarendon Press.

Zakon o dobrobiti životinja, Narodne novine, 19/99.

Zakon o zaštiti okoliša, Narodne novine, 80/13, 153/13, 78/15.

Zakon o zaštiti prirode, Narodne novine, 80/13.

Zakon o zaštiti životinja, Narodne novine, 102/17. 


\title{
LEGAL SYSTEM FOR THE PROTECTION OF LIFE, HEALTH AND WELFARE OF ANIMALS - BIOETHICAL APPROACH WITHIN THE LEGAL FRAMEWORK
}

\author{
Tomislav Nedić
}

\begin{abstract}
Since ancient times, animals have been present in human lives and their role has been extremely important. In addition, the coexistence between humans and animals, as well as humans and the entire living world, has an enormous importance for the preservation of the natural balance of the biosphere. Consequently, the bioethical awareness of humans towards animals is growing, resulting in some interesting legal considerations, which in turn raise certain questions. The legal system for the protection of life, health and welfare of animals is the main precondition for a peaceful and undisturbed coexistence between humans and animals. This paper takes this view as its starting point and uses comparative law, historical, case law and analytical methods in order to present the entire legal system for the protection of life, health and welfare of animals in the Republic of Croatia, together with all its elements. The aim of the paper is to show whether animals are subjects or objects of the existing laws, whether they have any subjective rights or are treated as protected legal goods, how the legal sources regulate this issue in the Republic of Croatia, and whether they directly protect animals' integrity. Based on the conducted research, the conclusion is that animals are considered to be legal objects (with a growing tendency within the practical and theoretical circles to change this status), guaranteed a direct protection of life, health and welfare as protected legal goods, through their own laws, principally the new Animal Protection Act and the animal cruelty provisions in the Criminal Code. Finding answers to these legal issues is a small but extremely important step in building a system of human solidarity towards animals in the form of a peaceful and undisturbed coexistence between humans and animals.
\end{abstract}

Keywords: bioethics, welfare, legal rights, life, animals

\section{RECHTLICHES SYSTEM ZUM SCHUTZ DES LEBENS, DER GESUNDHEIT UND DES WOHLBEFINDENS VON TIEREN - BIOETHISHER ANSATZ IM RECHTLICHEN RAHMEN}

\author{
Tomislav Nedić
}

\section{Zusammenfassung}

Schon seit Langem haben die Tiere im menschlichen Leben eine sichtbar wichtige Rolle. Das Zusammenleben von Menschen und Tieren aber auch dasjenige von Menschen und der gesamten lebendigen Welt ist von großer Bedeutung zur Erhaltung des natürlichen Gleichgewichts in der Biosphäre. Dadurch steigt das bioethische Bewußtsein des Menschen den Tieren gegenüber und bewegt interessante rechtliche Überlegungen, aus denen bestimmte Fragen entstehen. Das rechtliche System zum Schutz des Lebens, der Gesundheit und des Wohlbefindens von Tieren ist eine Voraussetzung für ein rubiges Leben und eine friedliche Koexistenz von Menschen und Tieren. Durch die Anwendung der vergleichenden Rechtswissenschaft, der Rechtssprechung, der geschichtlichen und analytischen Methode werden in der Arabeit das gesamte rechtliche System zum Schutz des Lebens, der Gesundheit und des Wohlbefindens von Tieren in Republik Kroatien, sowie alle zum Rechtssystem gehörenden Elemente kritisch erörtert. Das Ziel dieser Arbeit ist es, die Fragen zu beantworten, ob Tiere momentan als Subjekte oder Objekte des Rechtes betrachtet werden, ob sie subjektive Rechte haben oder ob es sich um geschützte rechtliche Güter handelt, auf welche Art und Weise die Rechtsquellen in Republik Kroatien diese Frage regeln und ob sie direkt die Integrität des Tieres schützen. Die 
Soc. ekol. Zagreb, Vol. 27 (2018.), No. 1

Tomislav Nedić: Pravni sustav zaštite ... životinja - bioetički pristup u pravnom okviru

Forschung in dieser Arbeit ist zum Schluss gekommen, dass Tiere im Moment als Rechtsobjekte verstanden werden (mit einer betonten Tendenz in praktischen und theoretischen Kreisen zur Änderung dieses Standes) denen das Rechtssystem den Schutz ihres Lebens, der Gesundheit und des Woblbefindens als geschützte rechtliche Güter garantiert, die es unmittelbar durch eigene Vorschriften schützt, vor allem, durch das neue Tierschutzgesetz und durch Blankettverweisungen mit Bezug auf Straftaten von Tötung oder Quälerei von Tieren im Strafgesetz. Die Antworten aufrechtliche Fragen sind ein kleiner, aber außerordentlich wichtiger Schritt zumm Aufbau eines Systems der menschlichen Solidarität den Tieren gegenüber im Sinne eines rubigen und ungestörten Zusammenlebens von Menschen und Tieren.

Schlüsselwörter: Bioethik, Wohlbefinden, Recht, Leben, Tiere 